These varietal names may seem perhaps unnecessary, but when one has already been referred to as a species by one of our leading authorities in this family, it shows how striking the variations are when isolated. There is a peculiar significance in the fact that these variations are apparently confined to the immediate seaboard, and their abundance there would indicate that they probably breed in the adjacent salt or brackish marshes. The question arises do these diversified conditions affect the species and give rise to these variations. On the other hand there is a similar though less pronounced variation in Tabanus trispilus. From New Jersey southward is found the typical form with dark brown wings, but to the northward the wings are much lighter in color, representing the var. sodalis Will. Another Tabanid, Chrysops fuliginosus or plangens, which is strictly a coastal species, distributed from Maine to Florida, shows considerable variation in the color of its wings, even in the same sex. Florida specimens have a distinct subhyaline streak dividing the apical spot from the crossband. Specimens from New Jersey northward have the brown of the wings more diffused and the streak less clearly defined.

\title{
A NEW SPECIES OF THE GENUS ULIDIA.
}

\author{
By Charles W. Johnson, \\ Boston Society of Natural History.
}

In a collection of Ortalidæ sent to me by Mr. E. P. Van Duzee for determination was the following apparently new species.

\section{Ulidia similis sp. nov.}

Head red, front punctate, each puncture bearing a short black hair, orbits pruinose, ocellar triangle black, one inner and one outer vertical and two post-vertical bristles, antennæ, palpi and proboscis reddish, arista blackish, thickened at the base. Thorax reddish, the disk black, covered with a grayish pollen and showing in a certain light two narrow dark vittæ, pleura red, between the front and middle coxæ blackish, two post-humerals, one pre-sutural, two supra-alar, one dorso-central, one notopleural, one mesopleural, and one sternopleural bristle, scutellum red, tips of the tarsi 
brownish. Wings hyaline, costal cell brown, stigma black, tip of the marginal, submarginal and first posterior cell clouded with dark brown. Halteres white. Length $5 \mathrm{~mm}$.

The female closely resembles the male. The first segment of the ovipositor is red, the tip blackish. Length $6 \mathrm{~mm}$.

Fourteen specimens, Los Banos, Merced Co., California, May 22, 1918, collected by Mr. E. P. Van Duzee. Holotype (No. 521), allotype (No. 522) and eight paratypes in the collection of the California Academy of Sciences. Four paratypes in the author's collection.

Similar to U. rubida Loew, but that species has a broader and smoother front, the scutellum and pleura are a brighter red and more polished, the abdomen is also more polished and the ovipositor entirely black, the wings are a whitish hyaline, the apical spot smaller, the inner edge straight, not sinuous, and the tip of the first posterior cell narrower.

\section{NEW MOSQUITOS FROM PANAMA.}

By C. S. Ludlow,

Army Medical Museum, Washington, D. C.

During the later months of the summer, in connection with the work at Army stations both in this country and abroad, some new forms belonging to different groups of mosquitos have been received at the Army Medical Museum, two of which are from Panama and the others from the A. E. F.-S. taken at four different stations in Siberia.

There have also been received from Siberia three species already described by Mr. Theobald, "Culicida togoi," "Culicida nipponi," and "Culex osakaënsis." These are Mr. Theobald's namings but some of these species have since been referred to other genera, by Mr. Edwards.

Some of the new species are described as follows:

Anopheles (Stethomyia?) niveopalpis sp. nov.

Female. Head: dark brown, practically black, covered with fine "tomentum," a frosty line around the eyes, a tuft of long slender white scales projecting forward between the eyes, white 

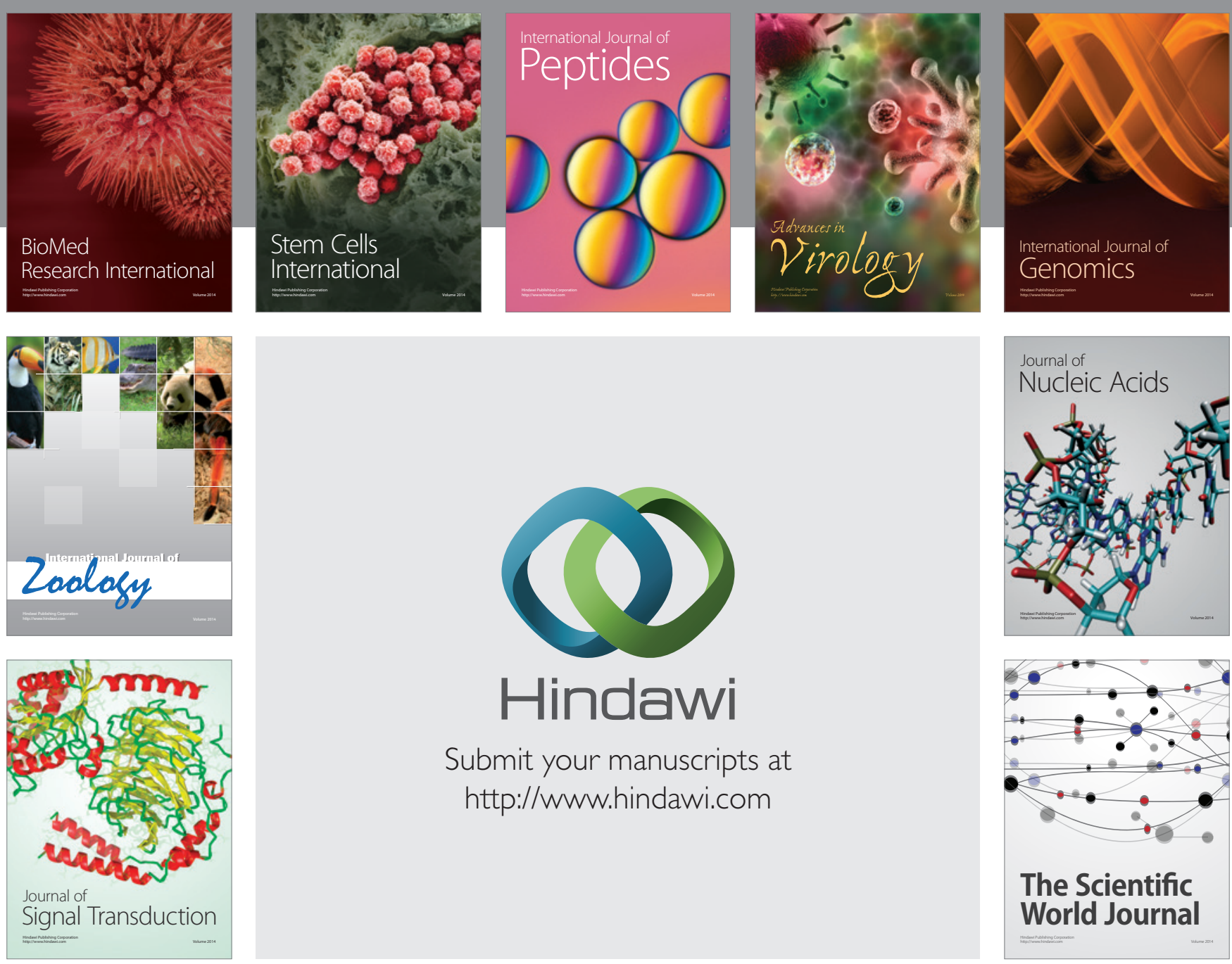

Submit your manuscripts at

http://www.hindawi.com
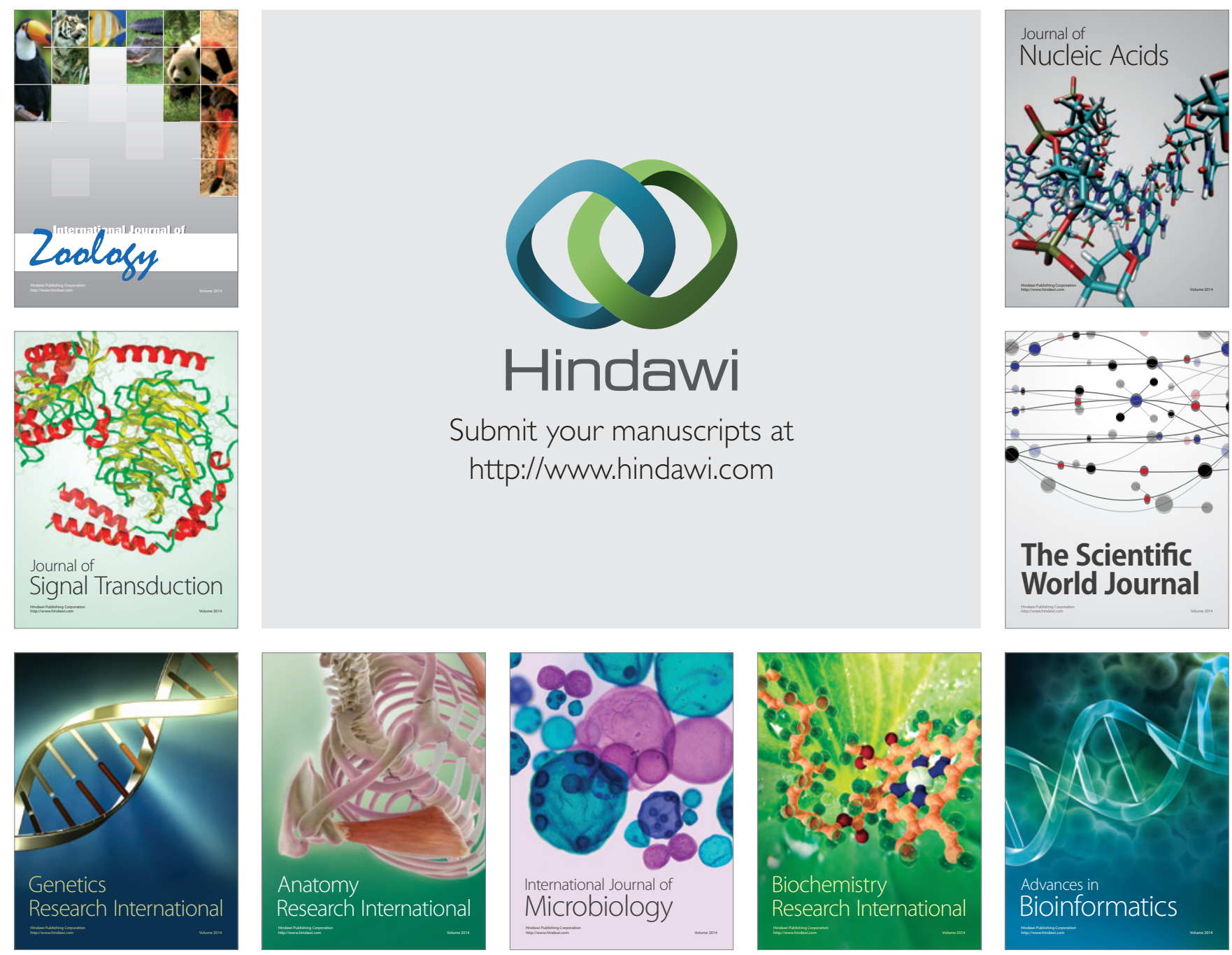

The Scientific World Journal
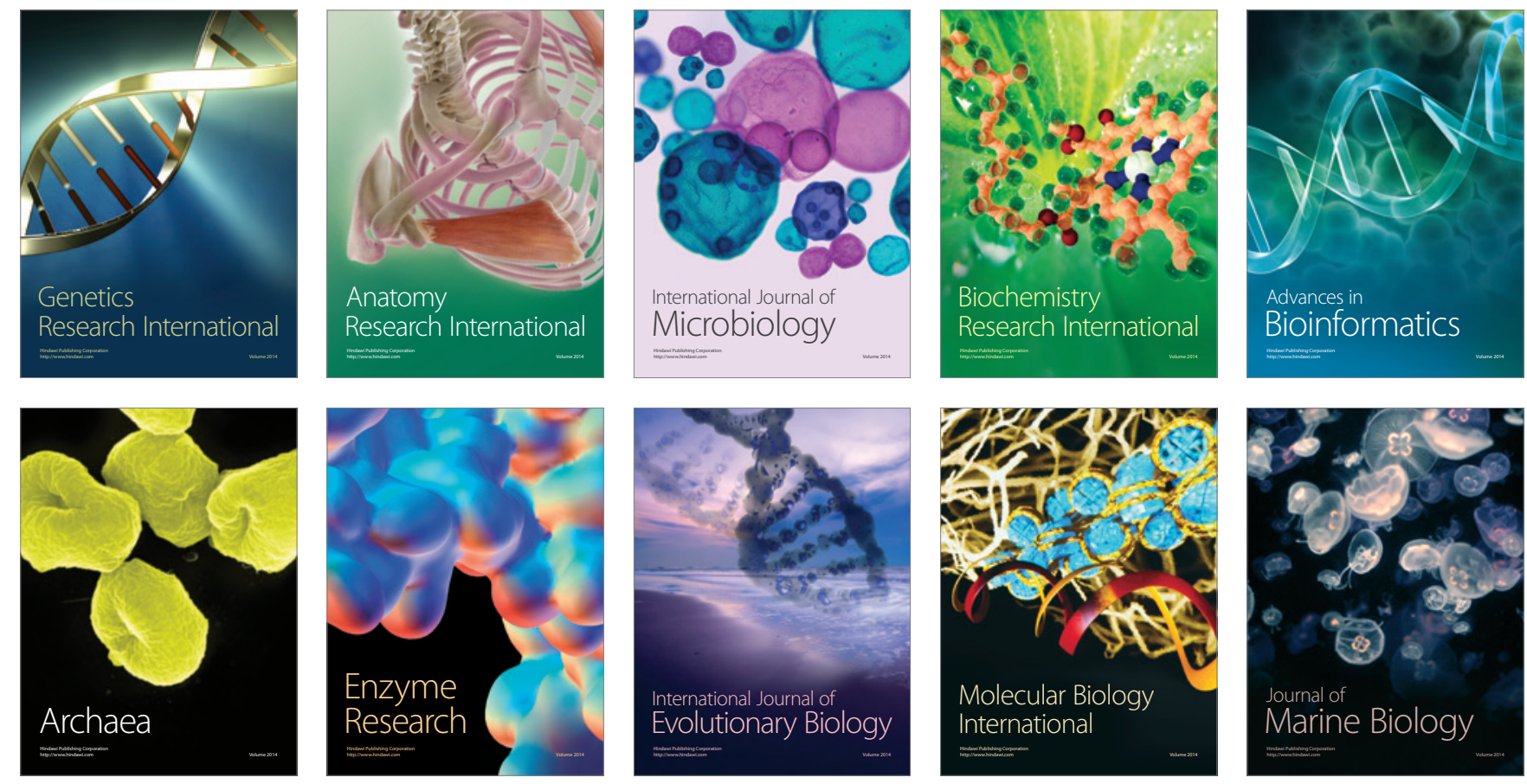